\title{
Pedagogical Formation Program Teacher Candidates' Attitudes Towards the Teaching Profession
}

\author{
Güner Tural \\ Ondokuz Mayıs University, Turkey \\ guner.tural61@gmail.com
}

\author{
Önder Kabadayı \\ Ondokuz Mayıs University, Turkey \\ onderkabadayi@gmail.com
}

\begin{abstract}
The teaching profession has important characteristics such as love and value which affect the success attained in the profession. This paper examines attitudes of teacher candidates toward teaching profession in terms of love, value and adaptation dimensions of the profession. Also it's aimed to determine change in the attitudes according to "gender," "graduation status" and "whether or not practiced teaching profession before." This study is a descriptive research in survey model. The sample of the study consists of eighty teacher candidates attending Pedagogical Formation Certificate Program. The 5-point likert-type attitude scale from literature consisting of "love", "value" and "adaptation" dimensions was used in this study. The findings show that the teacher candidates in pedagogical formation certification program have a positive attitude towards the teaching profession. The statistical evaluation of "value", "love" and "adaptation" subcategories revealed no significant difference with respect to graduation status and teaching experience variables. However a significant difference is observed in favor of female teachers when compared according to gender in love sub-category.
\end{abstract}

Keywords: Teaching Profession; Teacher Candidate; Attitude.

\section{Introduction}

Teaching methods and techniques are changing rapidly with advances in information technologies and thus expectations of teachers have increased in a similar way. The literature (Chapman \& Mählck, 1997; Châu, 1996; Darling-Hammond, 1999; Kanu, 1996; Mendro, 1998; Miguel \& Barsaga, 1997; Nye, Konstantopoulos, \& Hedges, 2004; Wright, Horn, \& Sanders, 1997) points out that a positive relationship between teacher quality and student achievement.

The teaching profession, which has the power to influence society in all areas, requires teachers who have cognitive, affective and psychomotor qualifications. The levels of these qualifications, will affect teacher candidates' success in the profession. In teacher training, a positive attitude about the profession is of great importance. The concept of attitude, which is one of the important indicators of affective characteristics, has different definitions in the literature. According to Papanastasiou (2002) attitude is defined as the emotional tendency of an individual to ideas, objects, people and places. Another definition of attitude is 'a psychological tendency that is expressed by evaluating a particular entity with some degree of favour or disfavour' (Eagly \& Chaiken, 1993, p. 1). 
There are many studies in the literature about teachers and teacher candidates' attitudes towards teaching profession (Aksoy, 2010; Bulut, 2009; Can, 2010; Chong, Low, \& Goh, 2011; Çapa \& Çil, 2000; Çapri \& Çelikkaleli, 2008; Demirtaş, Cömert, \& Özer, 2011; Dhammi, 2009; Durmuşoğlu, Yanık, \& Akkoyunlu, 2009; Eraslan \& Çakıcı; Erden, 1995; Gürbüztürk \& Genç, 1997; Kartal, 2009; Oral, 2004; Pehlivan, 2008; Sezer, Kara, \& Pınar, 2011; Şahin, 1992; Tanel, Kaya Şengören, \& Tanel, 2007; Üstün, Erkan, \& Akman, 2004; Yüksel, 2004). However, research on attitudes of teacher candidates who took courses within the Pedagogical Formation Training Certification Program towards the profession is limited.

Students who are participating in the Pedagogical Formation Certificate Program in Turkey represent a group for whom teaching was not their first choice of profession and who later decided to become teachers for various reasons. Pedagogical Formation Certificate Program continues in universities in Turkey where the Board of Higher Education has approved the opening. This program is four semesters in duration for students who attend undergraduate school and two semesters for graduate students. Students in Pedagogical Formation Certificate Program take courses to obtain teacher competencies in paralel to courses in education faculty programmes. These courses are: 'Introduction to Education,' Developmental Psychology,' 'Curriculum Development and Teaching,' 'Measurement and Evaluation,' 'Classroom Management,' 'Learning, Teaching Theories and Approaches', 'Guidance,' 'Special Teaching Methods, 'Instructional Technologies and Material Design' and 'Teaching Practice'.

Investigation the attitudes of candidates in the Pedagogical Formation Certificate Program attitudes towards the teaching profession is as important as studying the attitudes of those who are graduates of education faculties. Information on future teachers' attitudes towards the profession suggests directions for the development of positive attitudes before they begin teaching. Because, teacher candidates' attitudes towards the profession is important not only for themselves, but also for their attitudes' influence on students. If teacher candidates don't love and don't value to teaching profession and have negative judgements about it, these may affect negatively their professional achievements and satisfaction. It is not a desirable situation both for themselves and their students. If we know their attitude directions before they become a teacher, we can help them to gain positive attitude rather than negative attitude. So, it will be reflect positively to their affective qualifations and to educational environments.

\section{Purpose of the Study}

The purpose of this study was to examine attitudes of teacher candidates towards the teaching profession in terms of the love, value and adaptation dimensions of the profession. Also, it was intended to determine differences in attitude according to gender, graduation status and whether or not they had taught before. For this purpose following research questions are the frame for this study.

\section{Research Questions}

1. What is teacher candidates' attitude towards the teaching profession in terms of the love, value and adaptation dimensions of the profession?

2. Do the attitudes of teacher candidates towards teaching profession differentiate in terms of:

a) gender

b) graduation status

c) whether or not they had taught before. 


\section{Literature Review}

In the literature, we can see that researchers examined both teachers and teacher candidates' attitudes towards teaching profession. In this part, researches related to candidates were examined as present study includes teacher candidate sample.

Üstüner, Demirtaş, and Cömert (2009) investigated the attitudes of 593 teacher candidates towards teaching profession according to variables including their gender, the type of the department/program they study, the order of the program in the UEE (University Entrance Examination) preference list, the socio-economic status (SES) of the neighborhood and family they live in, the grade they attend, type of schooling, and the reasons for choosing teaching profession. A Likert type scale titled "Attitude Scale towards the Profession of Teaching" developed by Üstüner (2006) was used in the study. They found females' attitudes towards the profession more positive than males. In addition, significant differences were observed according to the type of the department/program they study, the order of the program in the UEE (University Entrance Examination) preference list, and the socio-economic status (SES) of the neighborhood, the reasons for choosing teaching profession, and family they live in.

Akbulut and Karakuş (2011) determined the attitudes of 239 secondary school science and mathematics (physics, chemistry, biology and mathematics) teacher candidates via "Teaching Professional Attitude Scale" developed by Özgür (1994). They examined the type of the program and grade variables. The findings revealed that teacher candidates' attitudes towards teaching profession were positive. There was no statistically significant difference among the programs but a significant difference was found according to the grades.

In order to evaluate 117 mother tongue (Turkish) teacher candidates' attitudes towards teaching profession according to their genders, socio-economic levels and grades, Güneyli and Aslan (2009) used 5-point Likert type attitude scale developed by Çetin (2006). A significant difference was found in favor of female teacher candidated in terms of gender variable. There was no significant difference according to socio-economic level and grade variables. Similarly, Çetinkaya (2009) identified 195 Turkish teacher candidates' attitudes towards teaching profession according to variables including gender, type of high school they graduated, the order of the program in the University Entrance Examination (UEE) preference list, and existence of a teacher in the family. The findings have indicated that variables such as the gender and the order of the program in UEE proved to be significant on the attitudes of the teacher candidates, whereas, variables such as the type of high school and existence of a teacher in the family had no impact. The findings revealed that Turkish teacher candidates' attitude scores towards teaching profession were higher and female teacher candidates' attitudes were more positive. Also Yeşil (2011) analyzed attitudes of the students who are studying in Turkish Language Teaching departments of the universities in Turkish Republic of Northern Cyprus towards teaching profession in terms of socio-demographic features. Result of the study presented that attitudes of the students of Turkish Language Teaching departments towards teaching profession were positive in general. Also their attitudes differentiated significantly in terms of gender, situation of being satisfied in their department, their parents' attitudes towards them, desire to become a teacher and do not differentiate significantly in terms of grade, mother's attitude towards them, income variables.

Oruç (2011) investigated the attitudes of 80 teacher candidates studying at a state university's English Language Teaching Department in Turkey towards teaching as a profession. A 30-item Likert type 
scale developed by Semerci (1999) was used to gather data and the results indicated that these teacher candidates have clear positive attitudes for their future profession.

Şimşek (2012) analyzed attitudes of 583 teacher candidates studying at Faculty of Technical Education on ability to take general roles of teachers with respect to class, gender, educational level of parents, reason to do major at the university, feeling themselves appropriate to the major, seeing themselves adequate, and desire to change the major. A 5-point Likert type attitude scale developed by the researcher was used and candidates' attitudes was found in the level of "Definetely I can". Female candidates' attitudes were more positive. No significant change was observed according to class levels but it was seen that departments that candidates study at affected their perceptions of competence of the teaching roles.

Hussain (2004) measured the development of professional attitude of 1200 secondary school teacher candidates of various teacher training institutions in Punjab with a 66-item Likert type attitude scale developed by him. Gender, duration of teacher training and science and arts graduates variables were taken into account. It was found that the trend in the development of attitude among female candidates was slightly greater than the male candidates. Also three years teacher training programme was more successful than one year and two years programme. The science and arts graduates exhibited no significance difference in the development of attitude.

Şahin Taşkın and Hacıömeroğlu (2010) examined attitudes of 223 final year teacher candidates studying in elementary education on teaching profession. "Attitudes Scale Towards Teaching" developed by Erkuş, Sanlı, Bağlı and Güven (2000) and open-ended questions were used to obtain the data. Findings indicated that there were differences between preservice teachers' attitudes and programs they enroll in but there was no significant difference between candidates' attitudes and gender. The results of the study also revealed that pedagogy courses influence teacher candidates' attitudes towards teaching positively. Çapri and Çelikkaleli (2008) used same scale to investigate the teacher candidates' attitudes towards teaching profession according to their gender, programs, and faculties. The findings revealed that gender had an important effect on attitudes towards teaching, program and faculty variables did not have any significant effect.

Eraslan and Çakıcı (2011) determined attitudes of 214 Faculty of Science and Arts students have Pedagogical Formation Program with respect to their grades, gender, department, type of high school, residence before coming to the university and choosing the education faculty at his/her university choices or not and such variables. They used 5-point Likert type attitude scale developed by Çetin (2006). It was found that there was significant difference in candidates' attitudes according to gender, choosing the education faculty at his/her university choices or not and department variables. In this study attitudes of male candidates more positive than female candidates unlike above studies.

These studies show that some variables may affect teacher candidates attitudes towards the profession. As seen above, most of the studies are related to students in Faculty of Teaching Programs. Researches about attitudes of Pedagogical Formation Program teacher candidates towards teaching profession are limited. So, this study will contribute the literature. 


\section{Method}

\section{Research Model}

Present study examines attitudes of teacher candidates towards the teaching profession is a survey model. Survey model is carried out to determine specific characteristics of a group (Büyüköztürk et al., 2011).

\section{Participants}

Approximately 400 students were announced in the classrooms about electronic survey on a voluntary basis. They were given two weeks to reply the survey and in this process the survey was reminded them. However 80 of them completed the electronic survey on a voluntary basis. They were teacher candidates in the Pedagogical Formation Certificate Program in one of the Black Sea Region universites in Turkey. They were in the second semester of the two term program in the 2011-2012 academic year. Together saving time and cost, it is difficult to obtain high return response rate from electronic surveys according to paper-and-pencil surveys. Krosnick (1999) in his study about survey research emphasized that

... the survey research community believes that representative sampling is essential to permit generalization from a sample to a population. Survey researchers have also believed that, for a sample to be representative, the survey's response rate must be high. (p. 539) But it is not necessarily true that representativeness increases monotonically with increasing response rate. Remarkably, recent research has shown that surveys with very low response rates can be more accurate than surveys with much higher response rates. (p.540)

The distribution of the sample with respect to subject area and gender is shown in Table 1.

Table 1. Teacher candidates participating in the survey by gender and subject area

\begin{tabular}{lll}
\hline & & N \\
\hline Gender & Female & 56 \\
& Male & 24 \\
\hline Subject area & Biology & 23 \\
& Physics & 15 \\
& Chemistry & 12 \\
& Mathematics & 7 \\
& Theology & 7 \\
& Geography & 4 \\
& History & 3 \\
& Literature & 3 \\
& English & 3 \\
& Music & 3 \\
\hline
\end{tabular}

\section{Data collection tools and application}

The data collection tool used in this study was the 'Teaching Profession Attitude Scale' developed by Çetin (2006). This is a Likert-type scale consisting of 35 items. There are three subscales: 'Love' (the first 22 items), 'value' (the next 8 items) and 'adaptation' (the last 5 items). In 'love' sub-category, the 
items $3,5,7,10,13,16,17,18,20,21$, and 22 consist negative opinions. There is no item has negative statement for 'value' sub-category. In 'adaptation' dimension, the items 31, 32, 34, and 35 consist negative opinions. The options were 'strongly agree', 'agree', 'undecided', 'disagree' and 'strongly disagree' for the scale. Positive statements were scored from 5 ('Strongly Agree') to 1 ('Never Agree'). Negative statements were scored opposite manner. In the factor analysis made in order to determine the structural validity of the scale, the factor loads of scale items varied between 0.48 and 0.80 and Kaiser-Meyer Olkin (KMO) value was found to be 0.95 . The Cronbach a reliability of the scale was reported as $r=.95$ (Çetin, 2006). The reliability of the survey was calculated again by researchers and Cronbach a was found as $r=.82$. So it can be said that the survey was reliable. The scale was transformed as electronic survey by researchers. So it was so fast and cost saving according to a paper-and-pencil survey.

\section{Analysis of the data}

The data collected from questionnaire were analysed using the Statistical Package for Social Sciences (SPSS) 17.0 using the frequency and percentage for each item, Levene's test and the independent samples $t$ test.

\section{Findings}

In this section, participants' responses to the scale of teachers' attitudes are given in tables as frequencies and percentages with respect to the love, adaptation and value subcategories. At the same time, changes in attitude toward the teaching profession are analysed according to gender, whether or not the respondents had taught before and their graduation status.

Table 2. Frequencies and percentages of teacher candidates' responses on the 'love' subcategory for the teaching profession attitude scale

\begin{tabular}{|c|c|c|c|c|c|c|c|c|c|c|c|c|}
\hline \multirow{2}{*}{\multicolumn{2}{|c|}{$\begin{array}{l}\text { Dimension } \\
\text { of love }\end{array}$}} & \multirow{3}{*}{$\frac{1}{23}$} & \multirow{3}{*}{$\frac{2}{25}$} & \multirow{3}{*}{$\begin{array}{l}3 \\
1\end{array}$} & \multicolumn{3}{|c|}{ Items } & \multirow{2}{*}{7} & \multirow[b]{2}{*}{8} & \multirow[b]{2}{*}{9} & \multirow[b]{2}{*}{10} & \multirow[b]{2}{*}{11} \\
\hline & & & & & 4 & 5 & 6 & & & & & \\
\hline \multirow[t]{2}{*}{ SA } & $f$ & & & & 17 & 0 & 37 & 16 & 15 & 11 & 10 & 22 \\
\hline & $\%$ & 29 & 31 & 1 & 21 & 0 & 46 & 20 & 19 & 14 & 13 & 28 \\
\hline \multirow[t]{2}{*}{$\mathbf{A}$} & f & 38 & 35 & 4 & 33 & 1 & 37 & 13 & 35 & 33 & 15 & 42 \\
\hline & $\%$ & 48 & 44 & 5 & 41 & 1 & 46 & 16 & 44 & 41 & 19 & 53 \\
\hline \multirow[t]{2}{*}{ UD } & f & 14 & 14 & 16 & 20 & 8 & 3 & 3 & 21 & 23 & 5 & 6 \\
\hline & $\%$ & 18 & 18 & 20 & 25 & 10 & 4 & 4 & 26 & 29 & 6 & 8 \\
\hline \multirow[t]{2}{*}{ NA } & $f$ & 3 & 3 & 24 & 7 & 19 & 2 & 14 & 6 & 11 & 13 & 7 \\
\hline & $\%$ & 4 & 4 & 30 & 9 & 24 & 3 & 18 & 8 & 14 & 16 & 9 \\
\hline \multirow[t]{2}{*}{ NEA } & $\mathbf{f}$ & 2 & 3 & 35 & 3 & 52 & 1 & 34 & 3 & 2 & 37 & 3 \\
\hline & $\%$ & 3 & 4 & 44 & 4 & 65 & 1 & 43 & 4 & 3 & 46 & 4 \\
\hline \multicolumn{2}{|c|}{$\begin{array}{l}\text { Dimension } \\
\text { of love }\end{array}$} & 12 & 13 & 14 & 15 & 16 & 17 & 18 & 19 & 20 & 21 & 22 \\
\hline \multirow[t]{2}{*}{ SA } & $\mathbf{f}$ & 20 & 1 & 21 & 16 & 2 & 19 & 2 & 36 & 1 & 2 & 1 \\
\hline & $\%$ & 25 & 1 & 26 & 20 & 3 & 24 & 3 & 45 & 1 & 3 & 1 \\
\hline \multirow[t]{2}{*}{ A } & $f$ & 40 & 5 & 45 & 23 & 9 & 46 & 1 & 36 & 4 & 0 & 5 \\
\hline & $\%$ & 50 & 6 & 56 & 29 & 11 & 57 & 1 & 45 & 5 & 0 & 6 \\
\hline \multirow[t]{2}{*}{ UD } & $\mathbf{f}$ & 13 & 6 & 9 & 25 & 12 & 7 & 7 & 6 & 8 & 4 & 16 \\
\hline & $\%$ & 16 & 8 & 11 & 31 & 15 & 9 & 9 & 8 & 10 & 5 & 20 \\
\hline NA & $f$ & 5 & 17 & 4 & 10 & 24 & 6 & 28 & 1 & 20 & 16 & 22 \\
\hline
\end{tabular}




\begin{tabular}{lllllllllllll}
\hline & $\%$ & 6 & 21 & 5 & 13 & 30 & 8 & 35 & 1 & 25 & 20 & 28 \\
\hline \multirow{2}{*}{ NEA } & $\mathbf{f}$ & 2 & 51 & 1 & 6 & 33 & 2 & 42 & 1 & 47 & 58 & 36 \\
\cline { 2 - 10 } & $\%$ & 3 & 64 & 1 & 8 & 41 & 3 & 53 & 1 & 59 & 73 & 45 \\
\hline
\end{tabular}

SA: Strongly Agree, A: Agree, UD: Undecided, NA: Not Agree, NEA: Never Agree

The frequencies and percentages of teacher candidates' responses on the 'love' sub-category were mostly positive. The highest percentage of 'Strongly Agree' answer was belong to the $6^{\text {th }}$ item. This item is: 'I believe that I will be more connected with the profession with increasing experience in the teaching." Samely, for 'Never Agree' answer, the highest percentage was belong to $21^{\text {st }}$ item. This item is: 'I'm unhappy with the thougt of being a teacher.'

Table 3. Relationship between opinions on the 'love' dimension and gender, teaching practice and graduation status

\begin{tabular}{llllllll}
\hline $\begin{array}{l}\text { Dimension } \\
\text { of love }\end{array}$ & & N & Mean & SD & t & df & P \\
\hline Gender & Female & 56 & 3.85 & .41 & 2.58 & 78 & $.01^{*}$ \\
& Male & 24 & 3.60 & .37 & & & \\
\hline Taught before & Yes & 35 & 3.86 & .34 & 1.78 & 78 & .08 \\
& No & 45 & 3.70 & .46 & & & \\
\hline Graduate & Graduated & 60 & 3.88 & .36 & -4.22 & 78 & $.00^{*}$ \\
status & Not grad. & 20 & 3.47 & .43 & & & \\
\hline
\end{tabular}

$* .05$ significance level

Levene's test was applied to determine whether the compared groups displayed equal variances. In the t-test calculations, evaluation of the results on Levene's test were taken into consideration. The results were interpreted according to the $5 \%$ significance level. A significant difference was observed in favour of female teachers, since $t=2.58, p=.01, p<.05$. When compared according to teaching experience, the difference was not significant $(p>.05)$. The attitudes of graduated and ungraduated students showed a significant difference in favour of the former.

Table 4. Frequency and percentages of teacher candidates' responses on the 'value' subcategory for the teaching profession attitude scale

\begin{tabular}{lllllccccc}
\hline \multicolumn{1}{l}{$\begin{array}{l}\text { Dimension } \\
\text { of value }\end{array}$} & $\mathbf{2 3}$ & $\mathbf{2 4}$ & $\mathbf{2 5}$ & $\mathbf{2 6}$ & $\mathbf{2 7}$ & $\mathbf{2 8}$ & $\mathbf{2 9}$ & $\mathbf{3 0}$ \\
\hline SA & $\mathbf{f}$ & 53 & 49 & 48 & 58 & 67 & 57 & 56 & 64 \\
\cline { 2 - 10 } & $\mathbf{\%}$ & 66 & 61 & 60 & 73 & 84 & 71 & 70 & 80 \\
\hline $\mathbf{A}$ & $\mathbf{f}$ & 25 & 29 & 29 & 20 & 11 & 22 & 22 & 15 \\
\cline { 2 - 10 } & $\mathbf{\%}$ & 31 & 36 & 36 & 25 & 14 & 28 & $\mathbf{2 8}$ & 19 \\
\hline UD & $\mathbf{f}$ & 0 & 1 & 1 & 1 & 1 & 0 & 0 & 0 \\
\cline { 2 - 10 } & $\mathbf{\%}$ & 0 & 1 & 1 & 1 & 1 & 0 & 0 & 0 \\
\hline NA & $\mathbf{f}$ & 1 & 0 & 0 & 0 & 0 & 0 & 1 & 0 \\
\cline { 2 - 9 } & $\mathbf{\%}$ & 1 & 0 & 0 & 0 & 0 & 0 & 1 & 0 \\
\hline NEA & $\mathbf{f}$ & 1 & 1 & 2 & 1 & 1 & 1 & 1 & 1 \\
\cline { 2 - 10 } & $\mathbf{\%}$ & 1 & 1 & 3 & 1 & 1 & 1 & 1 & 1 \\
\hline
\end{tabular}

SA: Strongly Agree, A: Agree, UD:Undecided, NA: Not Agree, NEA: Never Agree 
Most respondents chose the 'Strongly Agree' option, followed by 'Agree' option for the items regarding to dimension of value. This sub-category consists positive items. A relatively small number of teacher candidates chose other options. The item 'Teaching is an honorable profession' ( $27^{\text {th }}$ item) had the highest percentage in 'Strongly Agree' option.

Table 5. Relationship between opinions on the 'value' dimension and gender, teaching practice and graduation status

\begin{tabular}{llllllll}
\hline $\begin{array}{l}\text { Dimension } \\
\text { of value }\end{array}$ & & N & Mean & SD & t & df & P \\
\hline Gender & Female & 56 & 4.72 & .33 & 1.27 & 26.21 & .22 \\
& Male & 24 & 4.50 & .84 & & & \\
\hline Taught & Yes & 35 & 4.75 & .33 & 1.44 & 78 & .15 \\
before & No & 45 & 4.58 & .66 & & & \\
\hline Graduate & Graduated & 60 & 4.68 & .58 & -.73 & 78 & .47 \\
status & Not grad. & 20 & 4.58 & .42 & & & \\
\hline
\end{tabular}

There was no difference between teacher candidates in terms of gender, since $t=1.27 ; p=.22 ; p>.05$. There was also no significant difference in terms of teaching status $(t=1.44 p=.15 ; p>.05)$ or graduation status $(t=-.73 p=.47 ; p>.05)$ respectively.

Table 6. Frequency and percentages of teacher candidates' responses on the 'adaptation' subcategory for the teaching profession attitude scale

\begin{tabular}{llccccc}
\hline $\begin{array}{l}\text { Dimension } \\
\text { of } \\
\text { adaptation }\end{array}$ & $\mathbf{3 1}$ & $\begin{array}{c}\text { Items } \\
\text { ad }\end{array}$ & $\mathbf{3 3}$ & $\mathbf{3 4}$ & $\mathbf{3 5}$ \\
\hline SA & $\mathbf{f}$ & 0 & 0 & 0 & 5 & 1 \\
\cline { 2 - 7 } & $\mathbf{\%}$ & 0 & 0 & 0 & 6 & 1 \\
\hline $\mathbf{A}$ & $\mathbf{f}$ & 5 & 7 & 11 & 3 & 3 \\
\cline { 2 - 7 } & $\mathbf{\%}$ & 6 & 9 & 14 & 4 & 4 \\
\hline UD & $\mathbf{f}$ & 2 & 11 & 11 & 10 & 10 \\
\cline { 2 - 7 } & $\mathbf{\%}$ & 3 & 14 & 15 & 13 & 13 \\
\hline NA & $\mathbf{f}$ & 16 & 22 & 27 & 26 & 22 \\
\cline { 2 - 7 } & $\mathbf{\%}$ & 20 & 28 & 34 & 33 & 28 \\
\hline NEA & $\mathbf{f}$ & 57 & 40 & 31 & 36 & 44 \\
\cline { 2 - 7 } & $\mathbf{\%}$ & 71 & 50 & 39 & 45 & 55 \\
\hline
\end{tabular}

SA: Strongly Agree, A: Agree, UD:Undecided, NA: Not Agree, NEA: Never Agree

This sub-category consists of negative items. Teacher candidates' answers to these substances were mostly in the 'Never Agree' or 'Not Agree' options. The highest percentage was belong to 'Teaching is the latest profession for me as I get bored from lessons and teachers' for 'Never Agree' option.

Table 7. Relationship between opinions on dimension of 'adaptation' and gender, teaching practice and graduation status

\begin{tabular}{ccccccc}
\hline $\begin{array}{c}\text { Dimension } \\
\text { of } \\
\text { adaptation }\end{array}$ & N & Mean SD & t & df & P \\
\hline
\end{tabular}




\begin{tabular}{clllllll}
\hline Gender & Female & 56 & 3.89 & .45 & 1.90 & 78 & .06 \\
& Male & 24 & 3.68 & .45 & & & \\
\hline Taught & Yes & 35 & 3.85 & .45 & .27 & 78 & .79 \\
before & No & 45 & 3.82 & .47 & & & \\
\hline Graduate & Graduated & 60 & 3.88 & .51 & -1.59 & 78 & .12 \\
status & Not grad. & 20 & 3.70 & .43 & & & \\
\hline
\end{tabular}

There was no difference between teacher candidates in terms of gender, since $t=1.90 ; p=.06 ; p>.05$. There was also no significant difference in terms of teaching status and graduation status $(t=.27$ $\mathrm{p}=.79 ; \mathrm{p}>.05)$ and $(\mathrm{t}=-1.59 \mathrm{p}=.12 ; \mathrm{p}>.05)$ respectively.

\section{Discussion and Conclusion}

Generic teacher competencies consist of knowledge, skills and attitudes required to perform the teaching profession effectively and efficiently. A teacher's negative attitude towards teaching profession, even if he or she has high levels of subject knowledge and professional training, may affect students' performance negatively (Passos, 2009). Pre-service teacher education programmes of institutions of higher education for teacher education can make a difference on teacher candidates' professional identity. Therefore, teacher candidates' attitude towards teaching profession needs to be investigated in process of teacher education programmes to identify training needs according to results of the current status analysis. Pedagogical Formation Certification Program students' attitudes towards teaching profession should be investigated as education faculty students on account of they have right to be a teacher.

The present study findings showed that the teacher candidates in the Pedagogical Formation Certification Program had a positive attitude towards teaching profession. It is seen that (Table 2, Table 4 and Table 6), techer candidates' answers for 'love', 'value' and 'adaptation' sub-categories are positive. This could be a result of the effectiveness of the program. Şahin Taşkın and Hacıömeroğlu (2010) determined in their study that pedagogy courses influence teacher candidates' attitudes towards teaching positively. However teacher candidates' beliefs in teaching through their previous education may affect their current attitude. To determine the effectiveness of the Pedagogical Formation Certification Program, the 'Teaching Profession Attitude Scale' can be used at the point of entry and graduation from the programme.

Some studies show attitudes differing according to gender (Çapa \& Çil, 2000; Eraslan \& ÇakıCl, 2011; Güdek, 2007; Güneyli \& Aslan, 2009; Sağlam, 2008; Saracaloğlu, 1991; Soran, Demirci, \& Atay, 1996; Tekerek \& Polat, 2011) while others show no difference (Çapri \& Çelikali, 2008; Şahin Taskın \& Hacıömeroğlu, 2010; Tanel et al., 2007). However, in this study, a significant difference was found in favour of the female teacher candidates for the 'love' sub-category. This can be explained by the fact that the teaching profession is seen as a more female-oriented profession by Turkish society or that women are more disposed toward it (Çapri \& Çelikkaleli, 2008; Çetinkaya, 2009; Şimşek, 2012; Üstüner et al., 2009). There was no gender difference on the value and adaptation sub-scales.

The statistical evaluation of the sub-categories revealed no significant difference with respect to the graduation status or teaching experience variables. However these conclusions are limited with present study participants. Further study may be expanded with teacher candidates in the Pedagogical Formation Certification Program from various universities. 


\section{References}

Akbulut, Ö. E., Karakuş, F. (2011). The investigation of secondary school science and mathematics pre-service teachers' attitudes towards teaching profession. Educational Research and Reviews, $6(6), 489-496$.

Aksoy, M. E. (2010). Öğretmen adaylarının öğretmenlik mesleğine ilişkin tutumları. Sosyal Bilimler Araştırma Dergisi, 2, 197-212.

Aydın, A. (2003). Sınıf Yönetimi. İstanbul: Alfa Yayınclık.

Bulut, İ. (2009). Öğretmen adaylarının öğretmenlik mesleğine ilişkin tutumlarının değerlendirilmesi. Dicle Üniversitesi Ziya Gökalp Eğitim Fakültesi Dergisi, 14, 13-24.

Büyüköztürk, Ş., Kılıç Çakmak, E., Akgün, Ö. E., Karadeniz, Ş., \& Demirel, F. (2011). Bilimsel Araştırma Yöntemleri. Ankara: Pegem Akademi Yayıncılık.

Can, Ş. (2010). Tezsiz yüksek lisans öğrencilerinin öğretmenlik mesleğine yönelik tutumları. Muğla Üniversitesi Sosyal Bilimler Enstitüsü Dergisi (ÍLKE), 24, 13-28.

Chapman, D. W., \& Mählck, L. O. (1997). Changing what happens in schools: Central level initiatives to improve school practice. In Chapman, D.W., Mählck, L.O. and Smulders, A. (Eds.), From Planning to Action: Government Initiatives for Improving School Level Practice. Paris: International Institute for Educational Planning-UNESCO.

Châu, G. (1996). The quality of primary schools in different development contexts. UNESCO: International Institute for Educational Planning.

Chong, S., Low, E. L., Goh, K. C. (2011). Emerging professional teacher identity of pre-service teachers. Australian Journal of Teacher Education, 36(8), 50-64.

Çapa, Y., \& Çil, N. (2000). Öğretmen adaylarının öğretmenlik mesleğine yönelik tutumlarının farklı değişkenler açısından incelenmesi. Hacettepe Üniversitesi Eğitim Fakültesi Dergisi, 18, 69-73.

Çapri, B., \& Çelikkaleli, Ö. (2008). Öğretmen adaylarının öğretmenliğe ilişkin tutum ve mesleki yeterlik inançlarının cinsiyet, program ve fakültelerine göre incelenmesi. İnönü Üniversitesi Eğitim Fakültesi Dergisi, 15, 33-53.

Çetin, Ş. (2006). Öğretmenlik mesleği tutum ölçeğinin geliştirilmesi (Geçerlilik ve güvenirlik çalışması). Gazi Üniversitesi Endüstriyel Sanatlar Eğitim Fakültesi Dergisi, 18, 28-37.

Çetinkaya, Z. (2009). Identifying Turkish pre-service teachers' attitudes toward teaching profession. Elementary Education Online, 8(2), 298-305.

Darling-Hammond, I. (1999). Teacher quality and student achievement: A review of state policy evidence. Education Policy Analysis Archives, 8(1), 1-40.

Demirtaş, H., Cömert, M., \& Özer, N., (2011). Öğretmen adaylarının özyeterlik inançları ve öğretmenlik mesleğine ilişkin tutumları. Eğitim ve Bilim, 36(159), 96-111.

Dhammi, S. K. (2009). A study of attitude of elementary school teachers of Punjab in relations to sex, location, teaching experience and qualification. Procedia Social and Behavioral Sciences, 1(1), 2825-2827.

Durmuşoğlu, M. C., Yanık, C., \& Akkoyunlu, B. (2009). Turkish and Azerbaijani prospective teachers attitudes to their profession. H. U. Journal of Education, 36, 76-86.

Eagly, A. H., \& Chaiken, S. (1993). The psychology of attitudes. Fort Worth, TX: Harcourt, Brace, Jovanovich. 
Eraslan, L., \& Çakıcı, D. (2011). Pedagojik formasyon programı öğrencilerinin öğretmenlik mesleğine yönelik tutumları, Kastamonu Eğitim Dergisi, 2, 427-438.

Erden, M. (1995). Öğretmen adaylarının öğretmenlik sertifikası derslerine yönelik tutumları, HÜ Eğitim Fakültesi Dergisi, 11, 99-105.

Erkuş, A., Sanlı, N., Bağlı M. T., \& Güven, K. (2000). Öğretmenliğe ilişkin tutum ölçeği geliştirilmesi. Eğitim ve Bilim, 116, 27-33.

Güdek, B. (2007). Eğitim fakültesi müzik eğitimi anabilimdalı 1.ve 4. sınıf öğrencilerinin müzik öğretmenliği mesleğine yönelik tutumlarının öğrenciye ait değişkenler açısından incelenmesi (PhD Thesis). Gazi Üniversitesi Eğitim Bilimleri Enstitüsü, Ankara.

Güneyli, A., \& Aslan, C. (2009). Evaluation of Turkish prospective teachers' attitudes towards teaching profession (Near East University case). Procedia Social and Behavioral Sciences, 1, 313-319.

Gürbüztürk, O., \& Genç, S. Z. (1997). Sınıf öğretmenliği bölümü öğrencilerinin fakülteye ilişkin tutumları ile akademik başarıları arasındaki ilişki: Atatürk üniversitesi örneği. 4. Ulusal Eğitim Bilimleri Kongresi Bildirileri I: Program geliştirme, öğretmen yetiştirme, yaygın eğitim. Anadolu Üniversitesi Eğitim Fakültesi Yayınları, 51, 473-485.

Hussain, S. (2004). Effectiveness of teacher training in developing professional attitude of prospective secondary school teachers (PhD thesis). University Institute of Education and Research, University of Arid Agriculture, Rawalpindi, Pakistan.

Kartal, S. (2009). Tezsiz yüksek lisans programlarına devam eden öğretmen adaylarının öğretmenlik mesleğine yönelik tutumları. Selçuk Üniversitesi Ahmet Keleşoğlu Eğitim Fakültesi Dergisi, 28, 223-239.

Kanu, Y. (1996). Educating teachers for the improvement of the quality of basic education in developing countries. International Journal of Educational Development, 16(2), 173-184.

Miguel, M. M., \& Barsaga, B. E. (1997). Multi-grade schooling in the Philippines: a strategy for improving access to and quality of primary education - From Planning to Action: Government initiatives for improving school-level practice. Paris: International Institute for Educational Planning - UNESCO.

Krosnick, J. A. (1999). Survey research. Annual Review of Psychology, 50, 537-567.

Mendro, R. L. (1998). Student achievement and school and teacher accountability. Journal of Personnel Evaluation in Education, 12, 257-267.

Nye, B., Konstantopoulos, S., \& Hedges, L. V. (2004). How large are teacher effects? Educational Evaluation and Policy Analysis, 26(3), 237-257.

Oral, B. (2004). Eğitim fakültesi öğrencilerinin öğretmenlik mesleğine ilişkin tutumları. Eğitim Araştırmaları Dergisi, 15, 88-98.

Oruç, N. (2011). The perception of teaching as a profession by Turkish Trainee Teachers: Attitudes towards being a teacher. International Journal of Humanities and Social Science, 1(4), 83-87.

Papanastasiou, C. (2002). School, teaching and family influence on student attitudes toward science: Based on TIMSS data for Cyprus. Studies in Educational Evaluation, 28, 71-86.

Passos, A. (2009). A comparative analysis of the teacher competence and its effect on pupil performance in upper primary schools in Mozambique and other Sacmeq countries (PhD thesis). University of Pretoria, Pretoria. 
Pehlivan, K. B. (2008). Sınıf öğretmeni adaylarının sosyo-kültürel özellikleri ve öğretmenlik mesleğine yönelik tutumları üzerine bir çalışma. Mersin Üniversitesi Eğitim Fakültesi Dergisi, 4 (2), 151168.

Sağlam, A. Ç. (2008). Müzik öğretmenliği bölümü öğrencilerinin öğretmenlik mesleğine yönelik tutumları. Yüzüncü Yıl Üniversitesi EğitimFakültesi Dergisi, 5(1), 59-69.

Saracaloğlu, S. A. (1991). Fen ve edebiyat fakülteleri ögrrencilerinin ögrretmenlik mesleğine yönelik tutumları. 1. Eğitim Kongresi Bildirileri. İzmir. D.E.Ü. Buca Eğitim Fakültesi Yayınları, 565-569.

Semerci, Ç. (1999). Öğrencilerin öğretmenlik mesleğine ilişkin tutum ölçeği. Eğitim ve Bilim, 23(111), 51-55.

Sezer, A. Kara, H., Pınar, A. (2011). An investigation of non-thesis master's program geography teacher candidates' attitudes towards teaching profession regarding several socio-cultural features. US China Education Review, 8(5), 682-697.

Soran, H., Demirci, C., \& Atay, E. (1996). Hacettepe üniversitesi eğitim fakültesi fen bilimleri öğrencilerinin öğretmenlik mesleğine yönelik tutumlarının belirlenmesi. II. Ulusal Fen Bilimleri Eğitimi Sempozyumu, Marmara Üniversitesi Atatürk Eğitim Fakültesi, İstanbul.

Şahin, N. (1992). Arifiye anadolu öğretmen lisesi 3. sınıf öğrencilerinin öğretmenliğe ilişkin tutumları (Master Thesis). Hacettepe Üniversitesi Sosyal Bilimler Enstitüsü, Ankara.

Şahin Taşkın, Ç., \& Hacıömeroğlu, G. (2010). Examining preservice teachers' attitudes towards teaching profession in elementary education: A combination of quantitative and qualitative methods. Elementary Education Online, 9(3), 922-933.

Şimşek, C. (2012). Attitudes of teacher candidates studying at technical education on ability to take the role of a teacher. The Turkish Online Journal of Educational Technology, 11(2), 55-68.

Tanel, R., Kaya Şengören, S., \& Tanel, Z. (2007). Fizik öğretmen adaylarının öğretmenlik mesleğine ilişkin tutumlarının farklı değişkenler açısından incelenmesi. Pamukkale Üniversitesi Eğitim Fakültesi Dergisi, 2 (22), 1-9.

Tekerek, M., Polat, S. (2011). Öğretmen adaylarının öğretmenlik mesleğine ilişin tutumları. 5th International Computer \& Instructional Technologies Symposium, 22-24 September 2011, Firat University, Elazığ- Turkey

Üstün, E., Erkan, S., \& Akman, B. (2004). Türkiye'de okul öncesi öğretmenliği öğrencilerinin öğretmenliğe ilişkin tutumlarının incelenmesi. Manas Üniversitesi Sosyal Bilim/er Dergisi, 10(2), 129-136.

Üstüner, M., Demirtaş, H., \& Cömert, M. (2009). The attitudes of prospective teachers towards the profession of teaching (The case of Inonu University, Faculty of Education). Education and Science, 34(151), 140-155.

Wright, S. P., Horn, S. P., \& Sanders, W. L. (1997). Teacher and classroom context effects on student achievement: Implications for teacher evaluation. Journal of Personnel Evaluation in Education, $11,57-67$.

Yeşil, H. (2011). Turkish language teaching students' attitudes towards teaching profession. International Online Journal of Educational Sciences, 3(1), 200-219.

Yüksel, S. (2004). Tezsiz yüksek lisans programının öğrencilerin öğretmenlik mesleğine ilişkin tutumlarına etkisi. Uludağ Üniversitesi Eğitim Fakültesi Dergisi, 17(2), 355-379. 